\title{
Distribution and population density of the Endangered Cauca Guan Penelope perspicax
}

\author{
GUSTAVO H. KATTAN, ADRIANA LEÓN, GERMÁN CORREDOR, WILLIAM \\ BELTRÁN and MÓNICA PARADA
}

\section{Summary}

The original $24,900 \mathrm{~km}^{2}$ distribution of the Cauca Guan Penelope perspicax is currently reduced to less than $750 \mathrm{~km}^{2}$. In addition, forest within this range is fragmented and populations are isolated. We conducted surveys to determine the presence of the Cauca Guan at several locations within its present range, and mapped all known localities with guan records. Cauca Guan populations are confirmed to occur at only four sites, and the guan is absent from several localities with historic records. Some sites where the Cauca Guan is potentially present are highlighted. In particular, the possible existence of populations on the Pacific slope of the Andes requires confirmation, since a large habitat block is available. Population density estimates were obtained in two protected areas. In Yotoco Forest Reserve (559 ha) we estimated 8.6 guans km ${ }^{-2}$. At Otún-Quimbaya Flora and Fauna Sanctuary (489 ha), guans fed seasonally on leaves of Chinese ash Fraxinus chinensis, an exotic tree planted in a revegetation programme. Seasonal densities in ash plantations were over 100 guans $\mathrm{km}^{-2}$, whereas in mixed forest, mean density was 41.6 birds $\mathrm{km}^{-2}$. Ash has apparently become a key resource for this population. Although these two populations are within protected areas and have relatively high densities, they are small and isolated and require continued monitoring.

\section{Introduction}

The Cauca Guan Penelope perspicax is one of the most threatened species in the Neotropical family Cracidae (Endangered in the IUCN classification; BirdLife International 2000, Brooks and Strahl 2000, Renjifo 2002). It is endemic to the middle Cauca River watershed in western Colombia, in the Departments of Cauca, Valle del Cauca, Quindío and Risaralda. Its original distribution covered 24,900 km², but potential forest habitat within this range is reduced to about $750 \mathrm{~km}^{2}$ (Renjifo 2002). Therefore, the original extent of occurrence of this species has been reduced by $95 \%$. In addition, forest habitat in this region is highly fragmented (Kattan 1997) and remaining populations are isolated in a few fragments (Renjifo 2002).

The guan ranges between 1,000 and $2,000 \mathrm{~m}$ in altitude. It inhabits humid forest on both Andean slopes of the Cauca Valley (eastern slope of the Cordillera Occidental and western slope of the Cordillera Central; Figure 1), including forest edges and secondary growth (Nadachowski 1994, Silva 1996, Renjifo 2002). Apparently it also occupied dry forest on the Cauca Valley plateau and dry to semi-arid forest in the Patía Valley (Negret 1991). Some historical records are as low as $650 \mathrm{~m}$ (Renjifo 2002), and there is a 1930 secord by the late ornithologist F. C. Lehmann at Sonso Lagoon on the Cauca Valley plateau. At present the Cauca Valley plateau and the Patía Valley are 


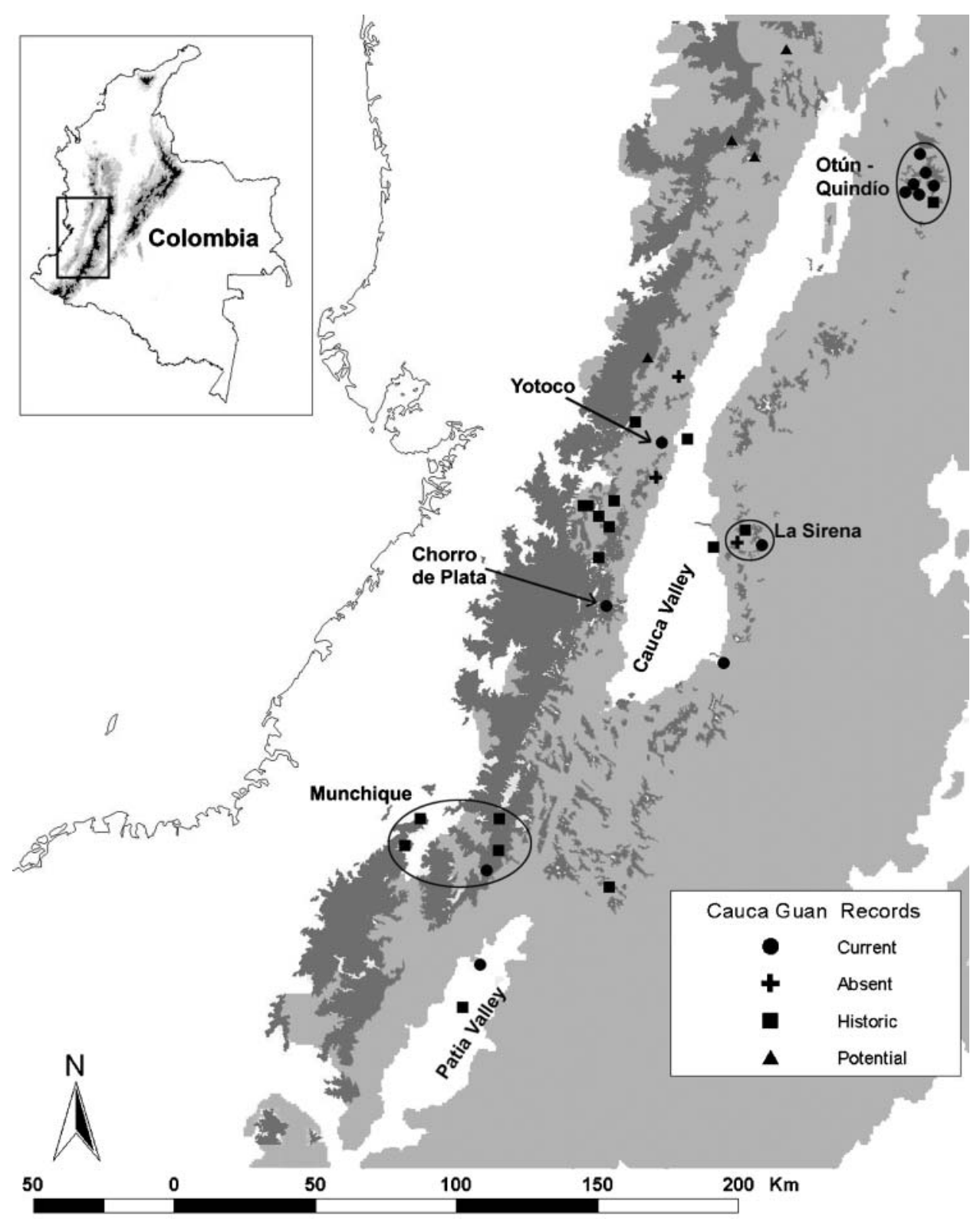

Figure 1. Map of south-western Colombia, showing the area of distribution of the Cauca Guan. The light grey shading indicates the western and central ranges of the Andes ( $1,000 \mathrm{~m}$ contour), and the dark shading indicates remaining forest fragments. The large area of forest on the west is on the Pacific slope of the Andes, between altitudes of 1,000 and 2,000 $\mathrm{m}$. The presence of Cauca Guan populations in this region is unconfirmed. 'Current' refers to localities with records after 1980, 'historic' refers to records before 1950, 'absent' indicates localities where we failed to find guans during this study, and 'potential' refers to localities where we recorded guan vocalizations but visual confirmation was not obtained, and thus the identity of the guan is uncertain. The insert shows the location of the Cauca Valley in Colombia. See text for explanation of localities. 
deforested, and forest within the altitudinal range on both Andean slopes is reduced to isolated fragments, although continuous forest exists at altitudes $>2,000 \mathrm{~m}$. Some recent records report the Cauca Guan at altitudes above 2,000 $\mathrm{m}$, but it is not clear whether the guan is expanding its altitudinal range (Renjifo 2002).

Most information on the ecology of the Cauca Guan is anecdotal. One study conducted at Yotoco Forest Reserve (559 ha), on the eastern slope of the western Andean range, reported on diet and other aspects of the guan's ecology (Silva 1996). This study reported a population of 45 individuals in this isolated reserve, but presented no data to support this figure. Nadachowski (1994) censused cracids along transects at Ucumarí Regional Park (1,80o-2,400 m, 4,240 ha), on the western slope of the Central range of the Andes. This author reported Cauca Guan densities that varied over 6 months between $<10$ and $>_{45}$ individuals $\mathrm{km}^{-2}$. Cauca Guans at Ucumarí used a variety of forest types, including monospecific tree plantations of Chinese ash Fraxinus chinensis. Ash produces dry fruits, and Nadachowski (1994) reported guans feeding on the unripe fruits of these exotic trees.

Although populations of Cauca Guan occur inside protected areas, these areas are small and isolated. Determining size and viability of these populations requires more precise information on population densities and sizes. On the other hand, guans are known to occupy small forest fragments (Renjifo 2002), and some fragments are available outside protected areas on both slopes of the Andes. In this paper we report data on the current distribution and population density of the Cauca Guan. In addition to locality data compiled in Renjifo (2002), we conducted rapid surveys at several sites to establish the presence of guan populations. To obtain population density estimations, we counted guans along transects at two sites, Yotoco Forest Reserve and Otún-Quimbaya Flora and Fauna Sanctuary, adjacent to Ucumarí Regional Park. At Otún-Quimbaya, we established transects across forest and ash plantation, to understand in more detail the use of this habitat by guans.

\section{Study area and methods}

The Cauca Valley is a sedimentary basin framed by the Western and Central Cordilleras of the Colombian Andes (Figure 1). The middle Cauca Valley forms a plateau of about $4,000 \mathrm{~km}^{2}$ at a mean altitude of $950 \mathrm{~m}$ and slowly descends northwards. This plateau was originally covered in wetlands, flooded forest and dry forest, but presently it is highly urbanized and the main land use is industrial agriculture. Only a few small remnants of dry forest remain (Álvarez-López and Kattan 1995). The slopes of the middle and upper Cauca Valley are also highly fragmented, but stretches of continuous forest still exist at altitudes above 2,000 $\mathrm{m}$, along the crests of the mountain ranges. The Cauca Guan was presumably originally distributed throughout this entire region.

We obtained maps of remnant forest for this region from two sources. WWFColombia provided maps produced for the Northern Andes Ecoregional project, which are based on satellite images. Our second source was Corporación Autónoma Regional del Valle del Cauca (CVC), the regional environmental authority, which provided a map for the Cauca Valley Department. This map is based on a variety of sources of information, including aerial photographs and ground surveys. We located on the map all known localities for Cauca Guan reported in Renjifo (2002). We conducted a 5- to 10-day exploration at 1o localities between May 2000 and June 2001, to determine the 
presence of guans (Table I). At each of these sites, we also made observations on habitat, landscape context and bird communities, as an indication of the ecological integrity of the site and its potential for supporting guan populations.

We used the variable-strip transect method (Franzreb 1981) to determine population densities at two sites: Yotoco Forest Reserve and Otún-Quimbaya Flora and Fauna Sanctuary. Yotoco is an isolated, 559 ha forest fragment, at altitudes between 1,400 and $1,600 \mathrm{~m}$, on the eastern slope of the Western Cordillera. Here we established four transects traversing the reserve, ranging in length from 500 to $1,800 \mathrm{~m}$ (depending on topography and accessibility). These transects were surveyed three times each during May and July 2000 and May 2001.

Otún-Quimbaya is a 489 ha reserve on the western slope of the Central Cordillera. This reserve is adjacent to Ucumarí Regional Park (4,240 ha), which stretches between 1,750 and $2,600 \mathrm{~m}$, so more habitat is available outside the sanctuary. These two

Table 1. Description of the localities surveyed for the presence of Cauca Guans in the Cauca Valley.

\begin{tabular}{|c|c|c|c|c|c|}
\hline Locality & Date & Site description & $\begin{array}{l}\text { Altitudinal } \\
\text { range (m a.s.l.) }\end{array}$ & $\begin{array}{l}\text { Cauca Guan } \\
\text { records }\end{array}$ & $\begin{array}{l}\text { Other } \\
\text { cracids }^{\text {a }}\end{array}$ \\
\hline $\begin{array}{l}\text { Fenicia } \\
\qquad 6.23 \mathrm{~W} \\
4.5 \mathrm{~N}\end{array}$ & Jun 2000 & $\begin{array}{l}\text { Two forest fragments } \\
<\text { 10 ha each }\end{array}$ & $1,700-1,850$ & Not recorded & O. mot. \\
\hline $\begin{array}{l}\text { La Zulia } \\
76.28 \mathrm{~W} \\
4.8 \mathrm{~N}\end{array}$ & Jun 2000 & $\begin{array}{l}\text { Continuous forest band } \\
\text { above } 2, \text { ooo } \mathrm{m} \text {, several } \\
\text { successional stages }\end{array}$ & $>_{1,800}$ & Vocalizations & C. goud. \\
\hline $\begin{array}{l}\text { Santa Ana } \\
76.45 \mathrm{~W} \\
3.79 \mathrm{~N}\end{array}$ & Aug 2000 & $\begin{array}{l}566 \text { ha forest remnant, } \\
\text { secondary growth }\end{array}$ & $1,200-1,650$ & Not recorded & $\begin{array}{l}\text { A. abur., } \\
\text { O. mot. }\end{array}$ \\
\hline $\begin{array}{l}\text { La Quisquina } \\
76.11 \mathrm{~W} \\
3.35 \mathrm{~N}\end{array}$ & Oct 2000 & $\begin{array}{l}<\text { Ioo ha forest remnant, } \\
\text { secondary growth }\end{array}$ & $1,550-2,000$ & Not recorded & $\begin{array}{l}\text { A. abur., } \\
\text { O. mot., } \\
\text { C. goud. }\end{array}$ \\
\hline $\begin{array}{c}\text { La Sirena } \\
76.7 \mathrm{~W} \\
3.32 \mathrm{~N}\end{array}$ & Nov 2000 & $\begin{array}{l}\text { Forest fragments and } \\
\text { riparian forest, several } \\
\text { successional stages }\end{array}$ & $>2,000$ & Visual records & $\begin{array}{l}\text { A. abur., } \\
\text { C. goud., } \\
\text { P. mont. }\end{array}$ \\
\hline $\begin{array}{l}\text { Chicoral } \\
76.35 \mathrm{~W} \\
3.36 \mathrm{~N}\end{array}$ & Nov 2000 & $\begin{array}{l}\text { Network of forest } \\
\text { fragments, several } \\
\text { successional stages }\end{array}$ & $1,850-2,000$ & Vocalizations & C. goud. \\
\hline $\begin{array}{c}\text { Las Brisas } \\
76.8 \mathrm{~W} \\
4.47 \mathrm{~N}\end{array}$ & Jan 2001 & $\begin{array}{l}50 \text { ha forest fragment } \\
\text { connected to higher } \\
\text { elevated forest through } \\
\text { riparian band }\end{array}$ & $2,000-2,350$ & Vocalizations & $\begin{array}{l}\text { A. abur., } \\
\text { C. goud. }\end{array}$ \\
\hline $\begin{array}{l}\text { San Antonio } \\
\text { (Chocó) } \\
76.12 \mathrm{~W} \\
4.49 \mathrm{~N}\end{array}$ & Jan 2001 & $\begin{array}{l}\text { Continuous forest on } \\
\text { both slopes over low } \\
\text { mountain pass }\end{array}$ & $>1,500$ & Vocalizations & $\begin{array}{l}\text { A. abur., } \\
\text { C. goud. }\end{array}$ \\
\hline $\begin{array}{l}\text { Planes de } \\
\text { San Rafael } \\
76.2 \mathrm{~W}_{5.7 \mathrm{~N}}\end{array}$ & Feb 2001 & $\begin{array}{l}\text { Continuous forest } \\
\text { above } 2,100 \mathrm{~m}\end{array}$ & $>2,100$ & Vocalizations & C. goud. \\
\hline $\begin{array}{l}\text { Chorro de } \\
\text { Plata } \\
76.36 \mathrm{~W} \\
3.20 \mathrm{~N}\end{array}$ & $\begin{array}{c}\text { Various } \\
\text { dates }\end{array}$ & 200 ha secondary forest & 1,200 & Visual records & O. mot. \\
\hline
\end{tabular}

${ }^{a}$ O. mot., Ortalis motmot; C. goud., Chamaepetes goudotti; A. abur., Aburria aburri; P. mont., Penelope montagnii. 
reserves protect the middle Otún River drainage. Forests in this area were exploited and fragmented during the early twentieth century. In the 1960s, local authorities began a revegetation programme to stabilize soils for watershed protection (Londoño 1994, Murcia 1997). As part of this programme, plantations of Chinese ash were established on a strip along the narrow valley bottom and other areas were abandoned to secondary succession. Ash plantations were not managed and are overgrown by native vegetation, currently forming part of the habitat mosaic that includes secondary forest patches of different ages, as well as areas of old-growth forest remnants (Medina et al. 2002, Durán and Kattan 2005, Lentijo and Kattan 2005). The patch of ash within the Sanctuary is about 18 ha, but more ash is available in adjacent Ucumarí Regional Park. At Otún-Quimbaya, we established one 3,60o m long transect through the ash plantation, and four transects $(1,200-2,040 \mathrm{~m}$ long) through mixed forest. These five transects were each surveyed one to four times per month, in II monthly surveys between August 1999 and June 2001.

To estimate population densities at both sites, we estimated the position perpendicular to the transect of each guan sighting in $5 \mathrm{~m}$ intervals, and plotted the frequency distribution of these sightings to obtain a detection distance. We defined this distance as the point of inflexion of the detection curve, where the number of detections dropped to less than $50 \%$ of the previous interval. Twice this distance multiplied by the length of the transect gave the area of the sampled band. Dividing the number of sightings by area gave the density of guans. When encountering flocks, we used the number of individuals in the flock for density calculations. This method assumes that we were detecting all individuals within the band, so densities may be underestimated. We used transects as sampling units, and repetitions of each transect in a given month as subsamples.

Detection distances were $30 \mathrm{~m}$ for ash and $10 \mathrm{~m}$ for mixed forest transects in OtúnQuimbaya, and $10 \mathrm{~m}$ for forest transects in Yotoco (we did not use distance-sampling procedures because our data violated some assumptions of this method). Detection distances were small because forest vegetation is dense. The ash habitat, on the other hand, is more open and trees are deciduous.

\section{Results}

We obtained visual Cauca Guan records at two of the 1o sites surveyed. The first site is Reserva La Sirena on the Central Andean range (Table 1, Figure 1). Here the guan occurs in small forest fragments and secondary growth in a pasture matrix. La Sirena is an environmental education centre managed by $\mathrm{CVC}$, the regional environmental authority of the Cauca Valley Department. There are some protected forest fragments around the centre, where the guan has been recorded by several observers (including A. L. and G. C.) over the last few years, and continuous forest exists at higher altitudes $(>2,000 \mathrm{~m})$. The status of this population is unclear and it is unknown to what extent the guan occurs in the continuous forest, where it may come into contact with the Andean Guan (P. montagnii). The second site is Chorro de Plata, a small (200 ha) secondary forest fragment in a suburban condominium in the outskirts of the city of Cali, altitude $1,200 \mathrm{~m}$. Recently, this forest fragment was declared a private reserve. This area is near Farallones de Cali National Park, so the extent of occurrence of this 
population needs to be evaluated, in particular around the El Topacio station in the park.

In five sites along the crest of the western Andean range, we recorded guan vocalizations but could not obtain a positive identification (Figure 1). At the other three sites we obtained no evidence of Cauca Guan presence (Table 1). One of these sites is a 566 ha forest fragment near Yotoco Forest Reserve, where a Cauca Guan population occurs. The two other sites have very small forest fragments ( $<_{10}$ ha). The three sites have populations of other species of cracids, however (Table 1 ).

Censuses at Yotoco produced population density estimates that varied in the three surveys between $6.5 \pm 8.1$ (SD) and $10.5 \pm 9.8$ individuals $\mathrm{km}^{-2}$, but variation among transects was high. This variation occurred because guans congregated at fruiting trees, so several guans were recorded in one transect and no guans in other transects. The mean of the three monthly censuses was 8.6 guans $\mathrm{km}^{-2}(95 \%$ confidence interval: 6.3-10.9). With this estimate, the 559 ha reserve could support a population of 35 to 61 individuals.

At Otún-Quimbaya FFS, population density estimates varied widely among transects and habitats (Table 2). Guans congregated in the ash plantation during November-February, where we observed them feeding on new leaf-shoots. This aggregation produced density estimates of 70 to over 100 individuals $\mathrm{km}^{-2}$. The number of guans in the ash plantation decreased during the middle of the year (MayOctober). Guan densities in forest transects showed the opposite pattern (Table 2). There were, however, no significant differences in guan densities among months in the forest habitat $\left(F_{9,38}=0.56, P=0.8\right)$, due to high variability among transects. The mean of monthly density estimates for forest transects at Otún-Quimbaya was 41.6 guans $\mathrm{km}^{-2}$ (95\% confidence interval: 29.4-53.9). With this estimate, there may be 144 to 264 individuals in the 489 ha reserve. More habitat is available in neighbouring Ucumarí Regional Park, so the local population size is larger.

Table 2. Population densities of Cauca Guan obtained in 11 monthly censuses in native forest ( $n=5$ transects) and ash plantation ( $n=1$ transect) at Otún Quimbaya Flora and Fauna Sanctuary, Central Andes of Colombia.

\begin{tabular}{lcl}
\hline Date & Ash plantation & Forest \\
\hline $\mathbf{1 9 9 9}$ & & \\
Aug & 74.1 & $29.4(27.2)$ \\
Nov & 109.6 & \\
Dec & 67.9 & \\
$\mathbf{2 0 0 0}$ & & \\
Jan & 88.0 & $30.9(61.7)$ \\
Feb & 67.9 & $24.7(49.4)$ \\
Mar & 23.2 & $57.6(70.4)$ \\
May & 15.4 & $49.7(27.0)$ \\
Jun & 0.0 & $55.6(33.9)$ \\
Jul & 6.2 & $6.1(12.2)$ \\
2001 & & \\
May & 0.0 & $54.0(36.1)$ \\
Jun & 0.0 & $35.9(71.8)$ \\
\hline
\end{tabular}

Data for forest transects are the mean of the five transects (SD). 


\section{Discussion}

The Cauca Guan presently occurs in only four confirmed areas (Figure 1): OtúnQuindío, La Sirena, Yotoco and Chorro de Plata. The most important, because it contains the largest cluster of habitat blocks, is the area labelled Otún-Quindío (Figure 1), in the Departments of Risaralda and Quindío, on the north-eastern corner of the guan's range. At this site, there is a cluster of guan populations, with a core at Otún-Quimbaya FFS and Ucumarí RP (in the Otún River drainage), and satellite populations in forest fragments around it, some of which are protected. Some of these fragments, however, are separated by pastures and other anthropogenic habitats, and it is unclear to what extent populations are isolated, or whether there is any movement of guans between fragments. Another important population occurs in Yotoco FR, on the eastern slope of the western range. This area is protected, but totally isolated from any other forested areas in the region. Surveys we conducted at two sites nearby, one in a 566 ha forest fragment south of Yotoco and at the same altitude, and the other in small fragments north of Yotoco, failed to produce any evidence of guan presence (Figure 1).

There are three sites in Cauca Department (southern portion of the guan's range) with relatively recent records (1980s), but they need to be re-evaluated. The most important is the area of Munchique, on the crest of the western range (Figure 1). Forest is still extensive here, and part is under protection in Munchique National Park. Negret (1991) recorded the Cauca Guan at Munchique in 1987, but in subsequent surveys failed to find it. Additional possible localities include the south-eastern fringe of the Cauca Valley, as well as the northern portion of the Patía Valley.

The guan is also potentially present at several sites on the north-western part of its range (triangles in Figure 1 ), where we recorded guan vocalizations but could not obtain visual confirmation. In this region, extensive forest exists at altitudes above 1,800-2,000 m, but here the western Andean mountain range has several low passes that connect to extensive forest between 1,000 and 2,000 $\mathrm{m}$ on the Pacific (western) slope (Figure I).

Estimates of population densities of guans vary widely. For example, estimates for P. jacquacu at Manu in Peru vary from 1 pair $\mathrm{km}^{-2}$ to 19.8 birds $\mathrm{km}^{-2}$ (Terborgh et al. 1990, Torres 1997). For P. barbata in the Andes of southern Ecuador, estimates at three sites varied from 2.3 to 17.1 birds $\mathrm{km}^{-2}$ (Jacobs and Walker 1999). Another study on P. montagnii in Andean Ecuador reported densities of 20 guans $\mathrm{km}^{-2}$ in farmland and 40 guans $\mathrm{km}^{-2}$ in primary forest (Creswell et al. 1999). Some of this variation may be attributed to the methodology used for estimating densities, but factors such as habitat productivity may produce spatial variation in density. Habitat fragmentation may also affect population densities through a variety of mechanisms, including resource availability. In addition, guans congregate at fruiting trees (or ash plantation in this study), and this behaviour may under- or over-estimate population densities, especially if sampling effort is small.

Our surveys at Otún-Quimbaya showed great spatial variation in population densities. Here, guans congregated in the ash plantation during November-January, the leaf flushing and fruiting season for ash, a deciduous species (Muñoz 2003). Ash stands have become an important resource for Cauca Guans, and also provide habitat for other bird species (Durán and Kattan 2005, Lentijo and Kattan 2005). It is not clear, however, whether guans are resorting to ash leaves because fruit availability is low in 
the forest (Muñoz 2003), or whether ash is a preferred food for these partially folivorous birds. Presumably, the ash plantation is attracting birds from a wide area, because densities within the ash patch when guans were aggregated, were very high (Table 2).

An important piece of information for more clearly establishing the status of the Cauca Guan, is to determine whether it is present in forest along the ridge of the Western Cordillera, especially near low passes, and on the Pacific slope. The presence of the Cauca Guan on the Pacific slope has always been conjectural and requires urgent confirmation, as a large habitat block is available. Two other Penelope guans (P. ortoni and $P$. purpurascens) occur in the Pacific slope at altitudes below 1,000 $\mathrm{m}$ (Hilty and Brown 1986), but except for isolated records (Negret 1991), nothing is known of guans in this region and how the different species may interact. In particular, Munchique National Park has several historic records of Cauca Guan and habitat is available, so there is good potential for finding a population.

Finally, populations of Cauca Guan are included in several protected areas (of which Otún-Quimbaya and Yotoco are the most important according to present knowledge), but these being isolated and small populations, vigilance through a monitoring programme is required. An ongoing ex situ conservation programme at the Cali zoo is also an important part of a strategy to save the Cauca Guan.

\section{Acknowledgements}

This study was funded through grants from the John D. and Catherine T. MacArthur Foundation, the Nando Peretti Foundation, the Instituto de Investigación de Recursos Biológicos Alexander von Humboldt, and the Corporación Autónoma Regional del Valle del Cauca (CVC). We thank staff at the Santuario de Flora y Fauna OtúnQuimbaya, Reserva Forestal de Yotoco (CVC), and Corporación Autónoma Regional de Risaralda (CARDER) for logistical support. World Wildlife Fund-Colombia and CVC kindly provided maps, and Andrés Trujillo, Olga Lucía Hernández and Carlos Valderrama helped produce maps of guan distribution. We thank Dan Brooks for comments on the manuscript.

\section{References}

Álvarez-López, H. and Kattan, G. H. (1995) Notes on the conservation status of resident diurnal raptors of the middle Cauca Valley, Colombia. Bird Conserv. Int. 5: 341-348.

BirdLife International (2000) Threatened birds of the world. Barcelona, Spain: Lynx Edicions.

Brooks, D. M. and Strahl, S. D. (200o) Cracids: status survey and conservation action plan. Gland, Switzerland: IUCN.

Creswell, W., Hughes, M., Mellanby, R., Bright, S., Catry, P., Chaves, J., Freile, J., Gabela, A., Martineau, H., McLeod, R., McPhie, F., Anderson, N., Holt, S., Barabas, S., Chapel, C. and Sánchez, T. (1999) Densities and habitat preferences of Andean cloud-forest birds in pristine and degraded habitats in north-eastern Ecuador. Bird Conserv. Int. 9: 129-146.

Durán, S. and Kattan, G. H. (2005) A test of the utility of exotic tree plantations for understory birds and food resources in the Colombian Andes. Biotropica 37: 129-135.

Franzreb, K. E. (1981) The determination of avian densities using the variable-strip and fixedwidth transect surveying methods. Studies Avian Biol. 6: 139-145.

Hilty, S. L. and Brown, W. L. (1986) A guide to the birds of Colombia. Princeton: Princeton University Press. 
Jacobs, M. D. and Walker, J. S. (1999) Density estimates of birds inhabiting fragments of cloud forest in southern Ecuador. Bird Conserv. Int. 9: 73-80.

Kattan, G. (1997) Transformación de paisajes y fragmentación de hábitats, ecosistemas terrestres. Pp. 76-82 in M. E. Chaves and N. Arango, eds. Informe nacional sobre el estado de la biodiversidad, tomo II. Bogotá: Instituto de Investigación de Recursos Biológicos Alexander von Humboldt.

Lentijo, G. M. and Kattan, G. H. (2005) Estratificación vertical de las aves en una plantación monoespecífica y en bosque nativo en la cordillera Central de Colombia. Ornitol. Colomb. 3: $48-58$.

Londoño, E. (1994) Parque Regional Natural Ucumarí, un vistazo histórico. Pp. 13-21 in J. O. Rangel, ed. Ucumarí: un caso típico de la diversidad biótica andina. Pereira, Colombia: Corporación Autónoma Regional de Risaralda.

Medina, C. A., Escobar, F. and Kattan, G. H. (2002) Diversity and habitat use of dung beetles in a restored Andean landscape. Biotropica 34: 181-187.

Muñoz, M. C. (2003) Características morfológicas, nutricionales y de disponibilidad de los frutos en la dieta de Penelope perspicax (Aves, Cracidae) en el Santuario de Flora y Fauna Otún Quimbaya, Risaralda. Thesis, Department of Biology, Universidad del Valle: Cali, Colombia.

Murcia, C. (1997) Evaluation of Andean alder as a catalyst for the recovery of tropical cloud forests in Colombia. For. Ecol. Manage. 99: 163-170.

Nadachowski, E. (1994) Observaciones sobre la ecología de cuatro especies de paujiles (Cracidae) en el Parque Regional Natural Ucumarí. Pp. 329-339 in J. O. Rangel, ed. Ucumarí: un caso típico de la diversidad biótica andina. Pereira, Colombia: Corporación Autónoma Regional de Risaralda.

Negret, A. J. (1991) Reportes recientes en el Parque Nacional Munchique de aves consideradas raras o amenazadas de extinción. Novedades Colombianas (Nueva Época) 3: 39-46.

Renjifo, L. M. (2002) Penelope perspicax. Pp. 124-130 in L. M. Renjifo, A. M. Franco, J. D. Amaya, G. H. Kattan and B. López, eds. Libro rojo de aves de Colombia. Bogotá: Instituto de Investigación de Recursos Biológicos Alexander von Humboldt.

Silva, L. (1996) Biología de Penelope perspicax (Aves: Cracidae) en la reserva Forestal de Yotoco, Valle del Cauca. Thesis, Department of Biology, Universidad del Valle: Cali, Colombia.

Terborgh, J., Robinson, S. K., Parker, T. A., Munn, C. A. and Pierpont, N. (1990) Structure and organization of an Amazonian forest bird community. Ecol. Monogr. 60: 213-238.

Torres, B. (1997) Densidades poblacionales de la comunidad de crácidos en el Parque Nacional Manú, Peru. Pp. 376-394 in S. D. Strahl, S. Beaujon, D. M. Brooks, A. J. Begazo, G. Sedaghatkish and F. Olmos, eds. Biology and Conservation of the family Cracidae. Washington: Hancock House Publishers.

GUSTAVO H. KATTAN*, ADRIANA LEÓN, WILLIAM BELTRÁN†, MÓNICA PARADA

Fundación EcoAndina/Wildlife Conservation Society Colombia Programme, Apartado Aéreo 25527 Cali, Colombia, Avenida 2 Oeste No. 10-54 Cali, Colombia.

$\dagger$ Present address: Department of Biology, University of Puerto Rico, San Juan, PR.

\section{GERMÁN CORREDOR}

Fundación Zoológica de Cali, Cali, Colombia.

*Author for correspondence; E-mail: gkattan@wcs.org 